\title{
Assessment of traffic pollution by using mosses Entodon concinnus and Herpetineuron toccoae
}

\author{
Sunita K apila*, T.A ggarwal and A nju Rao \\ Department of Botany, Panjab University,Chandigarh,INDIA \\ *Corresponding author. E-mail: s_kapila0802@yahoo.co.in \\ Received: J uly 31, 2010; Revised received:J une 10, 2012; Accepted: August 6, 2012
}

Abstract : Lead pollution resulting from vehicular traffic in Chandigarh,India was assessed by using two pleurocarpic, ectohydric mosses (Entodon concinnus and Herpetineuron toccoae) collected from pollution free area in Kasauli. Of the two mosses tested for lead accumulation, E. concinnus was found to be more efficient than $\mathrm{H}$. toccoae (50.3ppm vs 34.4ppm).

Keywords: Assessment, Lead accumulation, Lead content, Moss bags, Traffic pollution

\section{INTRODUCTION}

It is during the recent years (Ross, 1990; Ananyan et al. 1991; Al-Radady et al., 1993; Palmieri et al., 1997; Grodzinska et al., 1999; Herpin et al., 2001; Vanderpoorten et al., 2001; Zeichmeister et al., 2005), mosses have been increasingly utilized to monitor and control environmental pollution..Air pollution, particularly caused by vehicular emissions (ground level source of pollution) resulting from lead based additives TEL (Tetra-Ethyl Lead) and TML (Tetra-Methyl Lead) is one of the worst environmental problems, with great health hazards leading to tiredness, abdominal discomfort, anemia and paralysis.

The chronic lead toxicity causes insomnia, schizophrenia, mental confusion, mental dullness, poor memory etc. (Saxena, 2002; Dai and Fan,2006; Mitra et al. 2009). In this connection, Chandigarh - the composite capital of the states of Punjab and Haryana, is of special concern as evident from a recent report 'State of Environment of Chandigarh, 2004' which states that while the human population in the city has increased a little over three times from 1971 to 2001 , vehicular population during the same period has shot up by 42 times. The present study was taken up with a view to assess lead pollution at different sites of Chandigarh and devise easy, cheap and eco-friendly method to monitor and control vehicular traffic pollution.

\section{MATERIALS AND METHODS}

Two pleurocarpic, ectohydric and epiphytic mosses Entodon concinnus (De Not.) Par. and Herpetineuron toccoae (Sull. et Lesq.) Card. were collected from a pollution free location in Kasauli (Western Himalaya).

The plants were separated from the respective substrata, thoroughly cleaned and freed from other adhering moss taxa. These were then repeatedly washed with tap water followed by two final washings with distilled water. The plant materials were then dried between the folds of blotting sheet. Fifty-six bags of $10 \mathrm{~cm}$ x $10 \mathrm{~cm}$ nylon mesh were made and each bag was packed with two grams of each of the two moss samples.

Each moss bag was then immersed in very mild acid solution $(60 \mathrm{ml} \mathrm{HCl}+6$ litre distilled water) for 5 minutes to get rid of free-existing ions, and protonate the binding sites on cell wall to be later exchanged with heavy metal ions by the living moss from the atmosphere.

For the present study, following seven sites falling in different sectors of Chandigarh were selected. Site I PGI, Bus stand, Dividing road of Sectors 12 and 14; Site II - Roundabout of Sectors 16, 17, 22 and 23;Site III Traffic lights near Aroma Hotel,Sector 22; Site IVRoundabout of Sectors 29, 30, Industrial area I and Industrial area II (Tribune Chowk); Site V- Industrial area I(Near PVR Centra Mall);Site VI- Industrial area I(Near Paint Factory); Site VII - Near Sukhna Lake, Sector 6 (VIP area).

At each site, eight bags (four of each moss taxon) were hung at about $1.5 \mathrm{~m}$ height above ground on the branches or trunks of trees or poles exposed to traffic pollution . One bag of each moss was removed from each site at fortnightly intervals (for 2 months-July and August). The labeled moss samples were dried in an oven at $50^{\circ} \mathrm{C}-$ $60^{\circ} \mathrm{C}$. Then $200 \mathrm{mg}$ of each finely ground plant sample was digested in $10 \mathrm{ml}$ digestion mixture $\left(70 \% \mathrm{HNO}_{3}+\right.$ $\mathrm{HClO}_{4}$ in 3:1 ratio) on a sand bath till white to orange brown residue was left. To the residue was added $10 \mathrm{ml}$ of $10 \mathrm{mM} \mathrm{HNO}_{3}$ to get the stock solution. To $100 \mu \mathrm{l}$ of stock solution taken out by micropipette, HPLC analytical grade water was added to make the final volume as $10 \mathrm{ml}$ which was fed into Perkin Elmer analyst AA60 model of Atomic ISSN : 0974-9411 (Print), 2231-5209 (Online) All Rights Reserved @ Applied and Natural Science Foundation www.ansfoundation.org 
Absorption Spectrophotometer to determine the lead content in each sample.

The data collected from experimental studies were analyzed statistically using SPSS software. TWANOVA was done with Multiple Comparison (Post Hoc Tests) for Lead accumulated by Moss bags of both the mosses at different sites for variable number of exposure days.

\section{RESULTS}

The analyzed lead content (mean values in $\mu \mathrm{g} / \mathrm{g}$ ) in the Moss bags of both the mosses at different sites exposed for different intervals of time is tabulated in Tables 1 and 2. Statistically, the concentration of lead in both the mosses differed significantly between studied sites $(p<0.001$ to $\mathrm{p}<0.05$ ). There was also significant difference in lead accumulation with increase in the time period of exposure to emission from vehicular traffic ( $p<0.001$ to $p<0.05$ ).

\section{DISCUSSION}

The results in this study tabulated clearly establish that both the moss taxa, namely, Entodon concinnus and $\mathrm{H}$ erpetineuron toccoae are very efficient in aerial absorption of Lead from the atmosphere. This appears to be related to the greater surface area of relatively smaller, but more numerous leaves per square millimeter of the plant axis in E. concinnus.

After 15 days of hanging of Moss bags, fast uptake of lead was observed in both $E$. concinnus (Table 1) and $H$. toccoae (Table 2) at all the sites. Further increase in the concentration of accumulated Lead was very gradual. E.

Table 1. Lead content in $\mathrm{E}$. concinnus.

\begin{tabular}{ccccc}
\hline Site & \multicolumn{5}{c}{ Lead content in $\mu \mathrm{g} / \mathrm{g}$} \\
\hline I & In 15 days & $\ln 30$ days & $\ln 45$ days & In 60 days \\
\cline { 2 - 5 } II & 31.2 & 34.4 & 40.8 & 40.8 \\
III & 31.2 & 37.6 & 39.0 & 39.6 \\
IV & 32.5 & 38.4 & 42.5 & 42.8 \\
V & 33.1 & 39.7 & 41.3 & 41.7 \\
VI & 26.8 & 36.2 & 38.6 & 39.6 \\
VII & 36.1 & 45.0 & 48.2 & 30.3 \\
\hline
\end{tabular}

Control value of lead content in moss plants before acid treatment- $20.2 \mu \mathrm{g} / \mathrm{g}$ and after acid treatment-11.4 $\mu \mathrm{g} / \mathrm{g}$.

Table 2. Lead content in $\mathrm{H}$. toccoae.

\begin{tabular}{|c|c|c|c|c|}
\hline \multirow[t]{2}{*}{ Site } & \multicolumn{4}{|c|}{ L ead content in $\mu \mathrm{g} / \mathrm{g}$} \\
\hline & In 15 days & In 30 days & In 45 days & In 60 days \\
\hline I & 22.1 & 25.1 & 28.1 & 28.1 \\
\hline II & 24.6 & 28.8 & 29.1 & 29.5 \\
\hline III & 23.6 & 25.7 & 29.2 & 29.4 \\
\hline IV & 24.2 & 27.5 & 30.5 & 31.7 \\
\hline V & 25.7 & 29.2 & 30.1 & 33.2 \\
\hline VI & 28.7 & 30.3 & 32.2 & 34.4 \\
\hline VII & 16.8 & 19.5 & 20.2 & 20.4 \\
\hline
\end{tabular}

Control value of lead content in moss plants before acid treatment- $18.4 \mu \mathrm{g} / \mathrm{g}$ and after acid treatment- $10.1 \mu \mathrm{g} / \mathrm{g}$. concinnus could accumulate more lead $(50.3 \mu \mathrm{g} / \mathrm{g})$ than $\mathrm{H}$. toccoae $(34.4 \mu \mathrm{g} / \mathrm{g})$ in 60 days, thus proving as a better accumulator of lead in a polluted site.

Of all the sites, Site VI (Tables 1 and 2) falling in Industrial area I (Near paint factory) showed maximum lead accumulation in moss bags. It is due to the cumulative effect of lead emitted by a paint factory and heavy vehicular traffic on the roads connecting Chandigarh with the satellite town Panchkula as well as emissions from other units of Industrial area. On the other hand, Site VII showed least accumulation of lead by both the mosses (33.2 $\mu \mathrm{g} / \mathrm{g}$ and $20.4 \mu \mathrm{g} / \mathrm{g}$ respectively). This site falling in VIP area, Sector 6 of Chandigarh experiences least traffic and hence low level of lead pollution.Site IV on the Chandigarh - Zirakpur road experiencing frequent plying of diesel driven heavy vehicles also shows heavy lead pollution in air as indicated by the lead content of both the exposed mosses. Likewise, at Site V in Industrial area I, both the mosses showed higher values of lead capture.

Varying levels of lead accumulation by both the mosses at Site I, II and III are indicative of different levels of pollution at these sites.It can be safely inferred from the present study that mosses have a remarkable potential to absorb aerial pollutants over their general surface and accumulate them in significant quantities. This underlines the importance of this group of plants in pollution monitoring and pollution control studies. Here, it is also pertinent to suggest that topiaries of mosses can be decoratively installed at pollution sites so as to check 


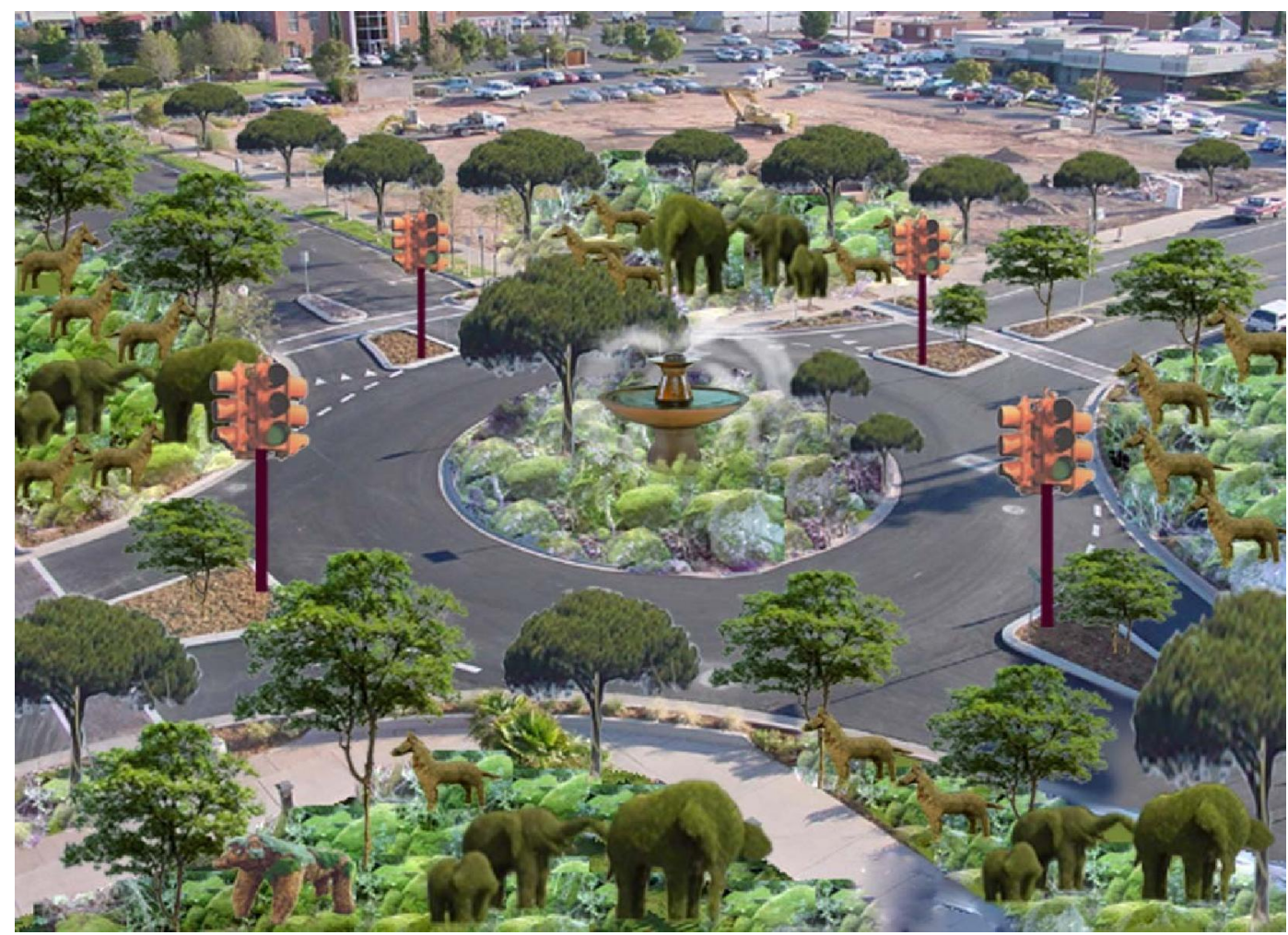

Fig. 1. Proposed traffic roundabout with moss topiaries and mosses growing all around it.

pollution at a low cost. Roundabouts (Traffic points) can be so designed as to have enough humidity and shaded areas to serve as habitats for growing these mosses (Fig.1). For instance, artificial waterfalls of Rock Garden in Chandigarh have now so many mosses (37 species) growing in their vicinity. Moss sticks, often used to support potted climbers, can also be utilized to lessen pollution of the vehicular traffic.

\section{REFERENCES}

Al-Radady, A..S., Davies, B.E. and French, M.J. (1993). A new design of moss bag to monitor metal deposition both indoors and outdoors. Science of the Total Environment, 133(3): 275-283.

Ananyan, V.L., Araratyan, L.A. and Manakyan, V.A. (1991). Accumulation of chemical elements and radionuclides in mosses. Ekologiya, $2: 82-85$.

Dai, Yao-Hua and Fan, Zhao-Yang (2007).Lead poisoning in Chinese children: risk factors and preventive measures, World J ournal of Pediatrics, 3 (2): http://www.wjpch.com/ UploadFile/001.pdf

Grodzinska, K., Szarek-Lukaszewska, G. and Godzik, B (1999). Survey of heavy metal deposition in Poland using mosses as indicators. Science of the Total Environment, 229(1-2): 41-51.

Herpin, V., Siewers, U., Kreimes, K. and Markert, B. (2001) Biomonitoring-evaluation and assessment of heavy metal concentrations from two German moss-monitoring
surveys.In: C.A. Burga and A. Kratochwil(Eds.), General and applied aspects on regional and global scales,vol.35 (pp.73-95)Tasks for Vegetation Science. Kluwer, Dordrecht, The Netherlands. 35: 73-96.

Mitra, Amal K., Haque, Akhlaque, Islam, Manirul and Bashar, S.A.M.K. (2009). Lead Poisoning: An Alarming Public Health Problem in Bangladesh. Int. J . E nviron. Res. Public H ealth, 6 (1): 84-95.

Palmieri, Franco, Neri, Roberto, Benco, Claudia and Serraca, Laura.(1997). Lichens and moss as bioindicators and bioaccumulators in air pollution monitoring. J ournal of Environmental Pathology, Toxicology and O ncology, 16(23): 175-190.

Ross, Howard B. (1990). On the use of mosses (H ylocomium splendens and Pleur ozium schreberi) for estimating trace metal deposition. Water, Air and Soil Pollution, 50(1/2): 63-76.

Saxena, A.K. (2002). Heavy Metals in the Environment ( Curse or Boon). Jaipur: Avishkar Publishers.

Vanderpoorten, A., Thiebaut, G., Tremolieres, M. and Muller, S. (2001). A model for assessing water chemistry using aquatic bryophyte assemblages in north-eastern France. Proceedings of International Association of Theoretical and Applied Limnology, 27: 807-810.

Zechmeister, H.G., Hohenwallner, D., Riss, A. and HanusIllnar, A..(2005). Estimation of element deposition derived from road traffic sources by using mosses. Environmental Pollution, 138: 238-249. 